Article

\title{
A Real Option Approach to Sustainable Corporate Tax Behavior
}

\author{
Anne Van de Vijver ${ }^{1, *}$, Danny Cassimon ${ }^{2}(\mathbb{D})$ and Peter-Jan Engelen ${ }^{3,4}$ \\ 1 Faculty of Law and Antwerp Tax Academy, University of Antwerp, Venusstraat 23, 2000 Antwerp, Belgium \\ 2 Institute of Development Policy, and Antwerp Tax Academy, University of Antwerp, Prinsstraat 13, \\ 2000 Antwerp, Belgium; danny.cassimon@uantwerpen.be \\ 3 School of Economics, Utrecht University, Kriekenpitplein 21-22, 3584 EC Utrecht, The Netherlands; \\ p.j.engelen@uu.nl \\ 4 Faculty of Business and Economics, University of Antwerp, Prinsstraat 13, 2000 Antwerp, Belgium \\ * Correspondence: anne.vandevijver@uantwerpen.be
}

Received: 27 May 2020; Accepted: 29 June 2020; Published: 3 July 2020

\begin{abstract}
Aggressive tax planning has become a sustainability problem, as governments have to cope with less tax revenue, which is crucial for investments in sustainable development goals. The OECD and the EU authorities have taken several initiatives against aggressive tax planning, such as the Action Plan against BEPS. However, these initiatives lack effectiveness, and aggressive tax planning is still omnipresent. We analyze the fight against aggressive corporate tax planning from a Real Option Theory perspective, in order to find an explanation for the difficult shift of companies' aggressive tax planning strategies to more sustainable tax behavior. The Real Option Theory shows that, as long as the option to 'delay' the investment in sustainable tax behavior has too much value because the benefits of such investment are uncertain, companies will wait. Based on this new understanding, we suggest additional public policy interventions against aggressive tax planning. These interventions aim directly at reducing this real option value (of waiting).
\end{abstract}

Keywords: real option theory; tax avoidance; BEPS; aggressive tax planning; sustainability

\section{Introduction}

While tax planning is traditionally a part of companies' strategic policy [1], especially aggressive types of tax planning have become a sustainability problem [2-4]. As Angel Gurría, the OECD Secretary-General, observed, taxation is crucial for inclusive growth and sustainable development. It provides governments with the revenues to invest in infrastructure, education, health, social protection systems [5], the environment and other sustainable development goals. However, aggressive tax planning undermines these public commons to the extent that governments have to cope with less tax revenue, which is crucial for such investments [2,6]. Although the estimated amount of the tax gap may vary depending on the definition of aggressive tax planning, a research paper of the European Parliament clearly shows the magnitude of the problem, and estimates the loss of tax revenue to the European Union (EU) Member States through aggressive corporate tax planning to be around 160-190 billion euros per year [7]. The European Commission suggests that Luxembourg, the Netherlands, Belgium, Ireland, Cyprus, Hungary and Malta appear to be employing aggressive tax planning structures [8]. In the United States, a study shows that the US Treasury is losing over $\$ 381$ billion per year because of tax avoidance and evasion [9]. Sadly, aggressive tax planning is also a huge problem for developing countries [10-13]. A study of the Dutch Centre for Research on Multinational Corporations shows that, as a result of Dutch tax treaties, developing countries lose 770 billion euro per year of withholding taxes on interest and dividends [14]. Other research 
estimates that multinationals relocate about $40 \%$ of their profits to tax havens each year [15]. Besides the financial dimension for government budgets, aggressive tax planning also undermines trust, shared understandings and commitments, and organizational integrity [2,16].

In the field of international taxation, legal scholars distinguish between tax evasion and tax avoidance. 'Tax evasion' is synonymous with tax fraud, and means criminal activity. It is defined as an illegal act of commission or omission that reduces or prevents a tax liability that would otherwise be incurred [17]. 'Tax avoidance' or 'tax planning' refer to any activity that is not criminal in nature but is aimed at the reduction of tax in order to maximize after-tax returns [18]. 'Aggressive tax planning' is a specific form of tax avoidance that is contrary to the spirit or the purpose of the law [19] (p. 58). In such cases, tax planning makes use of mismatches between tax systems: "instances where the interaction of different tax rules leads to double non-taxation or less than single taxation. It also relates to arrangements that achieve no or low taxation by shifting profits away from the jurisdictions where the activities creating those profits take place" [20]. This is also in line with the definition of the European Commission, which describes aggressive tax planning as "taking advantage of the technicalities of a tax system or of mismatches between two or more tax systems for the purpose of reducing tax liability" [8]. Overall, aggressive tax planning refers to companies taking advantage of loopholes in legislation [17] or opting for jurisdictions with weaker legal standards (i.e., tax havens) [21]. While formally complying with the letter of the law, aggressive tax planning plays the international tax rules as much as possible in order to reduce effective tax rates [22]. Conversely, companies that utilize sustainable tax behavior strategies want to contribute their fair share of taxes to ensure that governments receive feasible tax revenues $[2,3,23]$.

To address aggressive tax planning, international organizations have taken several countermeasures. The OECD has taken a leading role. At the request of the G20 finance ministers, the OECD developed the OECD Action Plan on Base Erosion and Profit Shifting ('OECD BEPS Action Plan') in 2013. The OECD BEPS Action Plan contains 15 actions that center around three pillars: substance, coherence and transparency [20]. The European Union makes specific efforts as well. The EU regulations adopted so far address tax avoidance practices [24], and introduce transparency requirements for tax rulings [25], multinationals' activities [26] and certain cross-border arrangements [27]. The basic aim of these countermeasures is to stimulate more sustainable tax behavior. According to the OECD, "enterprises should comply with both the letter and the spirit of the tax laws and the regulations of the countries in which they operate. Complying with the spirit of the law means discerning and following the intention of the legislature" [19]. Also, multinationals should refrain from lobbying for (excessively) favorable tax rules that disproportionally affect other taxpayers [22]. As such, sustainable tax behavior is also closely linked to corporate social responsibility ('CSR') [2,28-30].

The revelations of the International Consortium of Investigative Journalists (ICIJ) on the occasion of the LuxLeaks in 2014, Swiss Leaks in 2015, Bahama Leaks in 2016 and the Paradise Papers in 2017, however, reveal that aggressive tax planning is still omnipresent. Furthermore, the investigations of the European Commission show that the current actions against aggressive tax planning still lack effectiveness. For example, last year, the European Commission opened an investigation into a secret tax ruling granted by the Luxembourg tax authorities to the Finnish packaging group Huhtamäki [31]. This ruling is one of the 546 rulings that were disclosed by the ICIJ six years ago on the occasion of the LuxLeaks. However, the disclosures apparently did not (yet) convince firms to change their tax behavior. How can the difficult shift from aggressive tax planning to more sustainable tax behavior be explained?

This study uses economic theory to answer this question. The traditional economic model explaining business decisions is a net present value (NPV) or a cost-benefit (CB) model. When the direct pay-off from investment is positive (i.e., the benefits exceed the costs), conventional $\mathrm{CB}$ calculation indicates that it is interesting to go ahead with the investment. The seminal model of [32] uses a CB framework to explain tax avoidance and tax evasion. This model analyzes an individual taxpayer's decision on whether and to what extent to avoid taxes by deliberately underreporting 
earnings. The model shows that economic actors pay taxes because of the fear of detection and punishment, and is, in fact, an application of an economics of crime model in which a criminal trades off the benefits and costs of committing a crime [33]. If the apprehension rate is high, the actor would be better off declaring the actual income and avoiding penalties. If the probability for detection is low, the actor will be better off if they do not declare, and thus pay less taxes. The traditional implication for designing strategies to reduce tax avoidance and evasion is therefore to increase detection and penalty rates [34]. Later theoretical research extended or refined the model of [25], but remained within the framework of the CB model [35,36].

This study aims to contribute on a conceptual level to this strand of literature by applying Real Option Theory to tax planning decisions. A real option approach seems especially promising in this context, as it can address some of the limitations of the traditional CB/NPV-model. By explicitly allowing for flexibility in project design and in the timing of decision making, it incorporates the issue of how to optimally deal with uncertainty in the business environment in a fundamentally different way. Especially for projects that cannot be easily reversed once executed, this flexibility in timing and design may lead to a delay in executing positive $C B$ projects in order to gain more information and reduce uncertainty, so as to be able to make a better and more informed decision at some point in the future [37]. As such, it allows for a richer and more accurate analysis of such crucial elements as flexibility and uncertainty.

Although real option theory was originally developed and applied in the context of corporate investment decisions [38-40], this framework has also been applied to issues outside a corporate context, in areas such as global warming and sustainable energy solutions [41], criminal actions [42], and global public policy issues [43]. More recently, the real option approach was also applied to corporate decisions in a broader sense, such as, for example, investments in corporate social responsibility strategies [44]. This study introduces real option logic into the field of international taxation, and more particularly, to decisions that deal with ('investment' in) sustainable tax behavior. The application of real option logic was tested against empirical evidence from previous studies for the theoretical implications of this approach. Next, the effectiveness of the OECD BEPS Action Plan and the EU countermeasures were evaluated from this real option perspective. Based on real option logic, this study finds an explanation for the status quo, or at least the difficult shift towards more sustainable tax behavior. Finally, the study suggests public policy interventions to stimulate sustainable tax behavior. These suggestions consider the impact of stakeholder support, uncertainty, first mover advantage and the time window available to opt for sustainable tax behavior in the (near) future.

\section{Real Option Theory}

\subsection{Introduction of the Real Option Theory}

Real option theory states that any investment decision can be considered as exercising an option. An option is defined as the right (i.e., not an obligation) to buy (denoted as a call-option) or sell (denotes as a put-option) a particular ('underlying') asset at a specified price (denoted as the strike or exercise price) for a specific period (so-called 'American' options) or at a preset expiration date (as with so-called 'European' options) [45]. While the CB model infers a now-or-never approach, the real option theory makes it possible to attribute value to the postponement of taking the investment decision ('waiting'). As a result, real option logic is very useful in dealing with projects in uncertain environments, for which there is some flexibility in the timing of the decision and project design.

As a consequence of this option analogy, any decision to invest can be analyzed according to the model for financial options, i.e., executing a 'call' option on the benefits of such behavior (arising from the 'underlying' asset then achieved), by paying a given investment cost (the exercise price of the real option). As such, the six basic determining factors of the value of a classical stock option can be translated one-to-one into six basic determining value drivers in the real option set-up (see also the first two columns of Table 1). The stock price mutates into the present value of the (expected) benefits of the 
investment decision. The exercise price to be paid in order to acquire the underlying asset becomes the investment cost. Note that these two first parameters are identical to those used in the CB approach. The stock option analogy approach adds four parameters: risk, or volatility, is proxied as the standard deviation of the expected return on this investment. Time to maturity refers to the lifetime of the real option, which also refers to the length of the window of opportunity (indicating the degree of timing flexibility). Likewise, the risk-free interest rate enters into the calculation, with the same interpretation in both set-ups. Finally, the sixth element is the opportunity cost of waiting to invest [44]. In the case of a stock option, a dividend payment only accrues to the holder of the stock, not to the holder of the option; only when he has executed the option, will he be entitled to get the dividend payments, as they are attached to holding the underlying stock. Hence, the dividend yield acts as a kind of opportunity cost to holding the option, instead of holding the stock instead, which should act as an incentive to exercise the option. Translated to a real option context, a similar opportunity cost may occur; as long as firms wait, they can be exposed to opportunity costs. To give an example; postponing the launch of new products or services may result in a loss of market share or the loss of a first-mover advantage. Since this value-driver is also relevant for our analysis, we include the opportunity cost variable in our real option logic.

Table 1. Financial and real option analogy, value drivers and impact direction.

\begin{tabular}{cccc}
\hline $\begin{array}{c}\text { Financial Options } \\
\text { Definition }\end{array}$ & Real Options Analogy & $\begin{array}{c}\text { Real Options Applied to Sustainable } \\
\text { Tax Behavior (STB) }\end{array}$ & $\begin{array}{c}\text { Influence on } \\
\text { Option Value }\end{array}$ \\
\hline Underlying asset price & $\begin{array}{c}\text { Present value of expected } \\
\text { benefits of investment }\end{array}$ & $\begin{array}{c}\text { Present value of expected benefits of } \\
\text { STB (long-term stakeholder support) }\end{array}$ & + \\
\hline Strike price & Investment cost & Investment cost of STB (higher tax bill) & - \\
\hline $\begin{array}{c}\text { Volatility of underlying } \\
\text { asset return }\end{array}$ & $\begin{array}{c}\text { Volatility of return of } \\
\text { benefits }\end{array}$ & Volatility of STB benefits & + \\
\hline Time to maturity & $\begin{array}{c}\text { Window of opportunity } \\
\text { (timing flexibility) }\end{array}$ & $\begin{array}{c}\text { Window of opportunity(timing } \\
\text { flexibility) }\end{array}$ & + \\
\hline Risk free rate & Risk free rate & Risk free rate & + \\
\hline Dividend yield & Opportunity cost & $\begin{array}{c}\text { Opportunity cost(short-term } \\
\text { reputational risk) }\end{array}$ & + \\
\hline
\end{tabular}

On the basis of these parameters, the value of such an option can be calculated using standard financial option calculation models; the impact and interpretation of the different value-drivers in our real option case is identical to the financial options. For instance, as is also shown in the right-hand column of Table 1, whereas the present value of the (expected) benefits and the volatility have a positive impact on the value of the real option, the investment cost and the opportunity cost parameters impact the value negatively (see, e.g., [44] for details). As we are interested in understanding the influence of different parameters on the decision to adopt sustainable tax behavior, our analysis uses real option logic without relying on a specific quantitative model. For a formal model of real option logic, we refer to the Black-Scholes model [46] in Appendix A. However, in the following, we use this model in a more qualitative way, focusing on how each of this enhanced set of six parameters impacts on the option value (as so-called 'value-drivers'), and thus on a firm's decision to switch to a more sustainable tax policy, as well as how each of these value drivers can be linked to policy interventions.

\subsection{Sustainable Tax Behavior As a Real Option}

In this section, we argue that the decision to shift from aggressive tax planning to more sustainable tax behavior (STB) can also be analyzed according to real option logic. In our conceptual framework, we build on the earlier work of [44] and [47], where investments in CSR are presented as exercising a call option on accrued CSR benefits (with CSR constituting the underlying asset) by paying a particular 'investment in CSR' cost (the real option's strike price). The benefits of investing in CSR refer to the long-term sustainability of the support of the company's main stakeholders, enabling the firm to 
sustainably call upon the resources it needs [47]. Put differently, "refraining from investing in CSR can push major stakeholders to disengage from the company, with negative and potentially devastating effects on company value and/or even survival" [44] (p.18).

In a similar vein, we argue that a decision to invest in sustainable tax behavior can be defined as the exercise of a call option on the benefits of sustainable tax behavior (the underlying asset achieved upon exercising) by paying a particular investment cost (the exercise price of the real option). The decision to shift from aggressive tax planning to more sustainable tax behavior is an option, but no obligation, as tax rules in many ways lack precision and clarity, and are therefore a matter of choice of how to interpret the rules. Multinational corporations assisted by knowledgeable experts and advisors benefit from this leeway [22]. Multinationals determine their own strategy of complying with merely the letter of the law or also the spirit of the law, about taking advantage of loopholes or setting up structures in countries with weaker standards. Likewise, multinationals determine their own policy on lobbying in order to obtain beneficial tax treatment that may disproportionally affect other taxpayers.

Exercising the option to shift towards more sustainable tax behavior requires that such a decision adds sufficient value to the company and its stakeholders. The stakeholders must provide the necessary support and resources for the company to make this investment. The importance of the stakeholders, in this respect, resonates with previous research on the correlation between stakeholder support and aggressive tax planning. Previous research has suggested that aggressive tax planning has a negative influence on a firm's reputation, while sustainable tax behavior has a positive influence on a firm's reputation and stakeholders' support [48-50].

In this real option approach, stakeholder support is proxied by its impact on the value of the company. At some point, refraining from investing in sustainable tax behavior may incite major stakeholders to disengage from the firm, with negative consequences for the firm's value. As such, determining the value of investing in sustainable tax behavior for this case needs to focus crucially on how the particular major stakeholders view this decision [44]. Clients, employees, finance providers and public interest governors have been identified as major types of firms' stakeholders in the context of tax avoidance $[28,29,50]$. For instance, [51] found that, on average, the price of corporations' stock declines when news spreads about aggressive corporate tax strategies, while aggressive (sustainable) corporate tax planning strategies diminish (enhance) corporate success with consumers [21].

The decision to invest in more sustainable tax behavior can be influenced by the six parameters of real option logic (see also the third column of Table 1). The expected benefits of sustainable tax behavior can best be defined as the long-term sustainability effect of maintaining and even increasing the support of the firms' stakeholders. The investment cost of sustainable tax behavior consists in additional tax payments, which have a negative impact on the company's net operating profits. The volatility, measured as the standard deviation of the expected benefits, is the uncertainty with respect to increased or maintained stakeholder support. The time to maturity in a financial option, referring to the period during which the option can be exercised, is in fact a kind of 'window of opportunity', which is the term that we prefer to use here; it is the time frame during which the company has the choice, or the opportunity, to decide to invest in sustainable tax planning. Such a window would come to an end, for instance, through a (public) intervention by a global or country-specific regulatory body, stating that a specific form of tax avoidance would qualify as a criminal activity. The risk-free interest rate is merely a technical (discounting) parameter, and has the same interpretation as in a financial option. Finally, in the same sense as we have termed the time to maturity as a window of opportunity, the opportunity cost refers to the cost of not (yet) having used the opportunity, i.e., not having executed the option to invest in sustainable tax behavior.

These opportunity costs become more obvious when we look closer at these benefits of a sustainable tax behavior. First, as explained above, such behavior creates the possibility for the company to call upon stakeholders' support. Postponing such a decision therefore exposes the firm to a (gradual) loss of support from its (key) stakeholders, and also to an increasing reputational risk at the same time. Today's increasing transparency of tax matters increases the risk that aggressive tax planning structures will 
come to the surface through investigative journalists, activists or otherwise. Furthermore, foregoing the first-mover advantages of sustainable tax behavior may constitute an important opportunity cost, as "some specific outcomes of achieving first-mover advantage include being able to establish the firm as the benchmark against which all others are judged, setting the industry standards, influencing the direction of environmental regulations, and reinforcing the firm's reputation to embed legitimacy in the eyes of its stakeholders" [52] (p.360). Without taking into account opportunity costs, one can never capture the full dynamics of the decision process to move to sustainable tax policies.

\subsection{Consequences of the Real Option Perspective on the Decision to Shift to Sustainable Tax Behavior}

The real option theory also allows us to explain the slow and difficult shift from aggressive tax planning to more sustainable tax behavior. The basic consequence of presenting such a decision as exercising an investment option can be illustrated by comparing it to the CB model, which is the traditional model explaining tax planning. When the direct pay-off from tax planning, i.e., the difference between the present value of the benefits of tax planning and the investment cost, is positive, the conventional NPV calculation tells us that it is worthwhile to engage in tax planning. When a company engages in normal and appropriate tax planning, the present value after taxes increases because of the tax savings. However, if a company engages in aggressive tax planning or other inappropriate tax behavior which is not accepted by the relevant stakeholders, this can decrease the cash flow before taxes. The effective tax rate of the company is potentially lower, but the overall effect on net cash flows can be negative as a result of these actions and reactions [53]. The CB model can also be rephrased from this angle; when the direct pay-off of sustainable tax behavior, i.e., the difference between the present value of the benefits of sustainable tax behavior (e.g., reputation building) and the investment cost (e.g., additional tax payments) is positive, conventional CB calculation tells us that it is worthwhile to 'invest' in STB.

The advantage of starting from the real option perspective is that an alternative decision becomes clear. Another alternative for the firm is indeed to delay its decision to shift towards more sustainable tax behavior for some time. The advantage of such a delay is that it enables the firm to gain more information with respect to the uncertain environment, and that it may avoid being stuck in a loss-making and, to a certain extent, irreversible project (paying higher taxes). Waiting has value because the return on sustainable tax behavior (the benefits) is uncertain; while the expected benefits are based on current information, the benefit actually realized might be higher or lower than this mean. A higher uncertainty will result in a higher real option value (to wait). While the CB model is unable to capture this effect, real option logic shows that a company will postpone the decision on sustainable tax behavior as long as the value of waiting, as captured by the real option value, exceeds the value of investing now [44]. More particularly, unlike the CB approach, where the benefits are compared to the cost, the real option approach compares the value of keeping the option alive (i.e., deciding to wait, as measured by the option value) with the value of executing the option now (as measured by the NPV). As such, a firm will only decide to execute the option whenever the NPV exceeds the value of waiting, and decides to wait otherwise. Once the investment is done, the option is gone and the company loses its flexibility. Put differently, the value of the option is to be interpreted as the opportunity cost of investing (now), and hence must be added to the investment cost, leading the firm to decide to invest now only if the expected benefits are higher than the sum of the option value and the investment cost.

As such, the Real Option Theory provides the insight that the firm will wait until the conventional NPV is 'sufficiently positive' before committing resources to sustainable tax behavior, with the option value putting an exact number to this threshold value. As such, the exact decision to make is not (only) whether or not to invest (as indicated by the classic NPV criterion) but rather when to invest [44].

This is very relevant to explain the slow and difficult shift from rather aggressive tax planning to more sustainable tax behavior. As the return on this type of investment is perceived as being highly uncertain, companies prefer 'delaying' the investment, waiting for additional information to occur on the returns of sustainable tax behavior and/or the behavior of competing firms. The more uncertain the 
benefits are, the longer one will wait. In contrast, a higher opportunity cost of waiting will reduce the value of the option and will lead to the earlier execution of the option.

This insight is important, as it gives clear guidance to public policy interventions. Once governments understand the value drivers that impact firms' decisions (not) to invest in STB, they can influence one or more parameters to induce firms into STB. More particularly, as is also shown in Figure 1, the six implied parameters that have been identified above to drive the value of the option provide six potential levers that can be used by policy initiatives to influence the firms' optimal decisions. This can be accomplished, of course, by trying to increase the expected benefits of STB (lever 1) or reduce its costs (lever 2), which are the standard tools that would be derived from a CB approach, but the toolkit of possible interventions is extended through the real options lens in deriving interventions aiming at reducing the uncertainty of benefits, shortening the window of opportunity and increasing the opportunity cost of waiting. Some studies suggest that social and cultural environment also has an influence on corporate tax aggressiveness [54,55]. The Real Option Theory does not undermine these observations, and is able to capture a variation in tax aggressiveness. We will use this framework to discuss concrete policy interventions in the next sections.

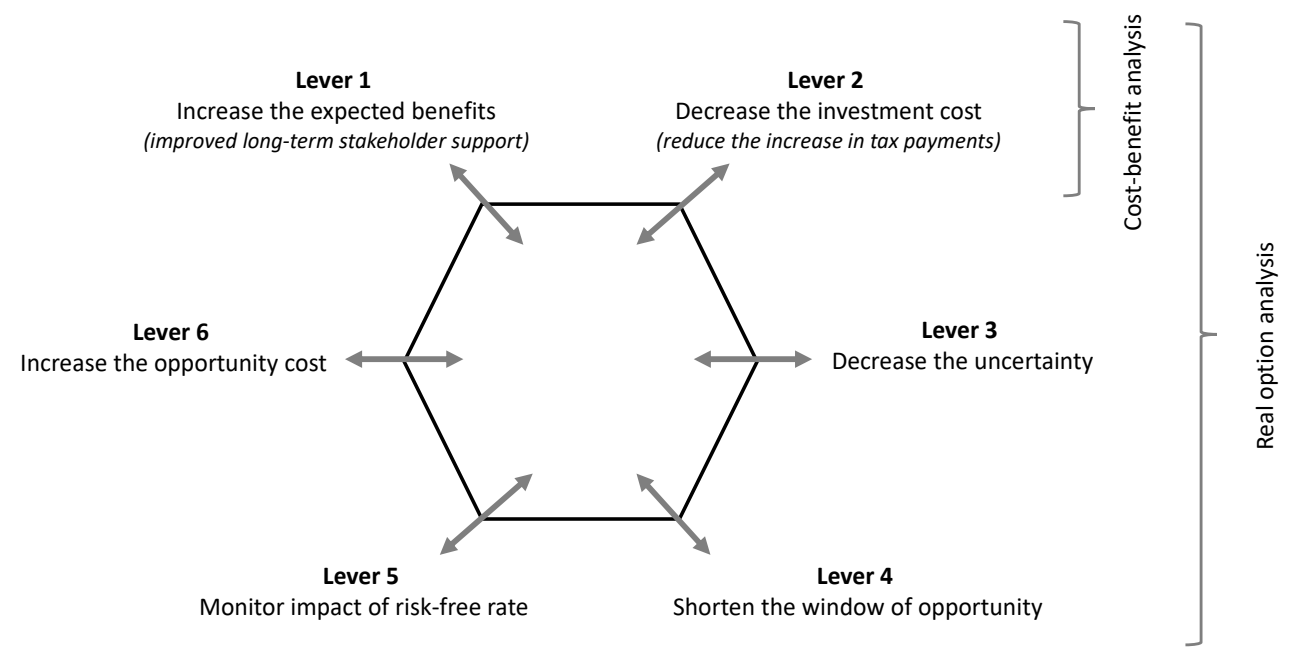

Figure 1. Policy interventions as an option value drive.

\section{Countermeasures from a Cost-Benefit Perspective}

The previous section showed how real option theory can explain firms' waiting behavior in switching to STB. In this section, we will analyze to what extent the OECD BEPS Action Plan and the EU countermeasures against aggressive tax planning fit within the different value-drivers of real option logic. The objective of the present contribution is not to discuss the OECD BEPS Action Plan nor the EU countermeasures in detail. To this end, we refer to other publications $[56,57]$.

Real option logic allows us to evaluate the effectiveness of the OECD and EU countermeasures in inducing firms to switch from aggressive tax planning to more sustainable tax behavior. In terms of real option logic, this means making sure that the NPV of sustainable tax behavior becomes larger than the option value (to wait). From a real option perspective, the conclusion is that the OECD and EU countermeasures only focus on two value-drivers, i.e., reducing the investment cost of sustainable tax planning and, to a lesser extent, increasing the expected benefits of sustainable tax behavior. In this section we briefly discuss the countermeasures adopted so far from a CB perspective. In the next section, we will show the additional levers that real option logic adds to the two levers of the CB model. 


\subsection{Countermeasures Reducing the Investment Cost}

The first category of countermeasures aims to lower the investment cost of forfeiting tax benefits resulting from aggressive tax planning when choosing more sustainable tax behavior. Action 5 of the OECD BEPS Action Plan is a good example of a countermeasure that results in a reduction of the investment cost of sustainable tax planning. It seeks to address preferential tax regimes that risk being used for artificial profit shifting from one country to another. The aim is to realign the taxation of profits with the typically geographically mobile activities that generate them (e.g., financial and other service activities, including the provision of intangibles). To this end, the OECD Member States agreed that countries can still have preferential tax rules for income from intellectual property ('IP regimes'), but subject to the conditions of the so-called 'nexus-approach'. First, the scope of application is limited to taxpayers that have invested in $\mathrm{R} \& \mathrm{D}$ (ratione personae). More specifically, tax benefits are reduced to the same proportion as the taxpayer contributed to the overall investment in $R \& D$ expenditures for the creation of the IP. The underlying idea is to encourage R\&D, but not IP shifting for tax purposes. Second, IP regimes are limited to patents and other IP assets that are functionally equivalent (ratione materiae) [58]. Aggressive tax planning outside this scope of application is not effective anymore since, based on the new rules, the benefit will cease to apply.

Similarly, a wide range of other OECD [20] and EU [24] countermeasures aim to limit the effectiveness of aggressive tax planning and thus, at the same time, reduce the investment cost of sustainable tax planning. These measures, more specifically, want to avoid treaty shopping, which involves strategies through which a person claims treaty benefits in situations where these benefits were not intended to be granted, by limiting the scope of application of treaty benefits to taxpayers who have a certain level of substance (no letterbox companies), neutralizing the effects of hybrid mismatch arrangements, increasing the effectiveness of controlled foreign company rules, limiting base erosion involving interest deductions, preventing artificial avoidance of permanent establishments and aligning transfer pricing outcomes with value creation. Within the boundaries of all these countermeasures, aggressive tax planning loses its effectiveness.

These examples show that the scope of the anti-abuse measures is limited, and typically focuses on a specific form of aggressive tax planning. As such, these measures can be circumvented by new aggressive tax planning schemes. In addition, the tax authorities of high-tax countries encounter many difficulties in fighting profit shifting to tax havens due to a lack of information, the harsh litigation positions of multinationals defending their planning structures in tax havens and a lack of cooperation by tax havens [15]. The anti-abuse measures, consequently, mainly focus on shifting profits to other high-tax places, but less on aggressive tax planning through low-tax jurisdictions [15].

The second category includes countermeasures to increasing tax transparency. The EU Directive 2016/881 of 25 May 2016 on country-by-country reporting is a good example of a countermeasure focusing on tax transparency and, as such, resulting in an increased investigation risk [26]. The Directive provides mandatory country-by-country reporting, whereby multinationals must report the amount of revenue, profit (loss) before income tax, income tax paid, income tax accrued, stated capital, accumulated earnings, number of employees and tangible assets other than cash or cash equivalents with regard to each jurisdiction in which the multinational operates. Furthermore, Member States must automatically exchange information on the country-by-country reports. Action 13 of the OECD BEPS Action Plan also introduced additional transfer pricing documentation obligations and country-by-country reporting [20]. The purpose of this action is to provide tax authorities with useful information for the assessment of transfer pricing and other BEPS risks, and to make determinations about where audit resources can most effectively be deployed. The assumption is that this information will enable tax authorities to identify aggressive profit shifting into low-tax environments [59].

Similarly, some other OECD [20,58] and EU [25,26] countermeasures aim at increasing tax transparency, such as the automatic exchange of tax rulings and mandatory disclosure of potentially aggressive or abusive tax planning schemes. 
The above-mentioned transparency countermeasures have in common that, to a large extent, they aim to render aggressive tax planning less effective by increasing the detection probability. Accordingly, the expected investment cost of forfeiting tax benefits resulting from aggressive tax planning when choosing for more sustainable tax behavior becomes lower.

\subsection{Countermeasures Increasing the Benefits of STB}

These OECD and EU transparency countermeasures also impact another value-driver, i.e., the long-term sustainability of stakeholder support, but only vis-à-vis one specific stakeholder, i.e., the tax authorities. The above-mentioned transparency countermeasures aim to provide more information to the tax authorities. Such information can affect the support of the tax authorities. In addition to the above-mentioned country-by-country reporting to the tax authorities, the European Commission adopted a proposal to introduce public country-by-country reporting. This proposal requires multinational groups to publish a yearly report on profits and tax paid in each country where they are active [60]. As such, other stakeholders would also have access to this information. This proposal, however, has not been adopted yet.

\subsection{Preliminary Conclusion}

From a real option perspective, we argue that the countermeasures in Sections 3.1 and 3.2 are insufficient to realize a shift towards more sustainable tax behavior. First, the scope of anti-abuse measures is limited, and can thus be circumvented. Second, the transparency measures only take into account one stakeholder, i.e., the government (tax authorities). However, other relevant stakeholders have also been identified, i.e., clients, employees, finance providers and the government as the public interest regulator. The countermeasures adopted so far do not aim to provide tax transparency to these other stakeholders. Finally, the countermeasures do not address other value-drivers impacting such decisions, such as the uncertainty of the benefits. Confronted with the trade-off between, on the one hand, the cost of investing now, in terms of additional tax payments in the short-run (investment cost), and on the other hand the long-term reputational impact, which is uncertain, it is understandable that companies decide not to invest in sustainable tax behavior at this moment.

This conclusion is in line with observations that, on the one hand, countermeasures adopted so far have achieved some results, but not enough. Since the publication of the OECD BEPS Action Plan in 2013, the various actions have been further developed and implemented in different countries. On 16 October 2017, the OECD published a Progress Report on Action 5 [58]. The report presents the results achieved by jurisdictions in implementing the 'nexus approach'. While, in 2015, the OECD still identified 16 IP regimes that were not in line with the 'nexus approach', now only one IP regime is still considered as harmful. This report shows progress in the field of the fight against aggressive tax planning.

However, the scope of the OECD BEPS Action Plan's 'minimum standards' is relatively narrow, and the Paradise Papers suggest that, so far, aggressive tax planning is still omnipresent. In 2016, Grant Thornton published the results of a survey that confirms this observation. The survey shows that 2600 businesses in 36 countries found little impact from the OECD BEPS Action Plan. In total, $78 \%$ of businesses said that they have not (yet) changed their approach to taxation. The Unhappier Meal Report, written by a coalition of European and American trade unions, even suggests that, in the face of initiatives against aggressive tax planning, McDonalds relocated its corporate structure from Luxembourg to a myriad of tax havens [61]. Legal scholars question the efficacy of the plan [62]. It is merely based on deterrence and does not address companies' societal responsibility [2]. It provides hard law anti-abuse rules that do not adjust to changing circumstances very quickly [2]. Furthermore, civil society organizations claim that the initiatives that have been developed so far lack ambition and are not effective [63].

In addition, as the countermeasures adopted so far target the expected benefits and the investment cost of a decision, they affect the NPV as well as the option value to wait in the same way. A reduction 
in the investment cost increases the NPV as well as the real option to wait. However, this intervention does lead to sustainable tax behavior occurring sooner because the effect on the NPV is larger than that on the option (to wait). However, in order to make this intervention more effective, it should make NPV become larger than the option (to wait). To that end, the level of intervention should be high enough to make companies switch [44]. Alternatively, the OECD and the EU may also consider making use of the other value-drivers, as explained in the next section.

\section{Additional Countermeasures from a Real Option Perspective}

The countermeasures adopted so far do not address other important value-drivers, such as the volatility (uncertainty), the opportunity cost and the opportunity window. Contrary to interventions impacting only the expected benefits and the investment cost, these interventions only affect the option value (to wait), and can be targeted to reduce this option to a level lower than the NPV, triggering immediate investment in sustainable tax behavior [44]. In this section, we suggest public policy interventions that may impact these value-drivers positively or negatively. The aim of these interventions is to reduce the value of the option (to wait) in order to stimulate companies to shift to sustainable tax behavior now (or in the near future). The interest rate-linked value-driver is typically considered exogenous, and will therefore not be further considered here.

\subsection{Countermeasures Reducing Uncertainty}

Real option logic shows that the uncertainty of the benefits of sustainable tax behavior increases the value of the real option to wait. Postponing the investment allows firms to gather more information with respect to the uncertain future environment, and to avoid being trapped in a loss-making project. Waiting has value because the return of sustainable tax behavior is uncertain. In order to stimulate companies to engage in more sustainable tax behavior now (or in the near future), this uncertainty should be taken away, or at least reduced.

This aspect concerns the uncertainty of how stakeholders will react to sustainable tax planning, what the expectations of the stakeholders are and to what extent they consider aggressive tax planning to be unacceptable or undesirable. As discussed above, some studies reveal reduced stakeholder support as a result of aggressive tax planning. However, the literature suggests that there is a gap in the expectations of sustainable tax planning approaches and dialogue between different stakeholder groups, i.e., on the one hand, corporate leaders and shareholders, and on the other hand, NGOs that have higher expectations [28,29]. Also, to the extent that the tax rules are not clear, it cannot be excluded that corporate leaders will defend tax planning based on the argument that they are fully compliant with the letter of the law (ignoring the spirit of the law) [64] and that stakeholders will approve (aggressive) tax planning [65]. Reference [65] claims that it cannot be ruled out that "the community of consumers, shareholders, and business partners do not view tax avoidance activities that fail to violate explicit tax rules as inconsistent with shared moral norms. By contrast, when the community perceives that a taxpayer has violated a clear tax rule in place at the time of the taxpayer's action, it may react to this perception with significantly more hostility" [65] (p.564). Or, "Short-term investors, like hedge and private equity funds, may be attracted to, rather than repelled by, corporations with tax directors who claim tax positions that 'push the envelope'" [65] (p.541).

Overall, however, research on the expectations of stakeholders in respect to corporate tax behavior is limited, and the conclusions diverge. For example, research focusing on the expectations of younger generations is lacking. What are the expectations of younger (future) employees in respect to corporate tax behavior? Research in the field of employer attractiveness suggests that the incorporation of sustainability into corporate strategy may better enable employers to attract millennials [66]. Future research could investigate whether sustainable corporate tax behavior also contributes to employer attractiveness. More generally, further research could contribute to bringing to light stakeholder expectations in respect to tax behavior and reducing the uncertainty in this respect. 
Legal scholars indicate that international tax law is the subject of substantial uncertainty; the boundary between aggressive tax planning and more sustainable tax behavior is vague [18]. The vaguer this boundary, the more room is left for different viewpoints in respect to tax planning approaches and, correspondingly, the more uncertainty of stakeholders' appreciations, expectations and reactions. The OECD BEPS Action Plan, to a certain extent, contributes more certainty about the boundary between aggressive tax planning and more sustainable tax behavior. From Action 6, for instance, one can derive that treaty shopping (see above) cannot be considered to be sustainable tax behavior. The scope of the OECD BEPS Action Plan is, however, limited and, to the extent that domestic anti-abuse measures remain a national matter, this leaves room for deviating definitions and corresponding uncertainty.

Since harmonization at the worldwide level is extremely difficult, public policy interventions could also try more to stimulate self-regulation by the private sector. Such self-regulation has already been implemented in other fields. For instance, the Business Social Compliance Initiative (a program of the Foreign Trade Association) supports working conditions through codes of conduct and audit procedures [67]. With the involvement of participating companies and stakeholders, it develops a broad range of tools and activities to monitor, train and share information to improve working conditions. It also organizes internal business audits amongst participating companies [67]. Following this example, business tax compliance initiatives may organize self-regulation in the field of taxation. Such self-regulation can include various aspects of sustainable tax behavior: the interpretation of statutes according to letter and purpose, refraining from aggressive lobbying, and reporting tax strategies and lobbying activities. The OECD and the EU may stimulate the (early) introduction of codes of conduct or, as already mentioned above, the integration of tax into a company's corporate social responsibility strategy [68] by initiating or participating in discussions or negotiations on industry codes or CSR strategies, or including the tax strategy in sustainability reporting [2].

In addition, the OECD BEPS Action Plan does not address aggressive tax lobbying. However, research shows that multinationals are very effective at lobbying for disproportionate tax incentives, to the detriment of other taxpayers [22]. In the field of lobbying, the OECD has already developed some initiatives. The starting point is that lobbying is a democratic right, and also has advantages. Governments can benefit from the data, insights and expertise of lobbyists. However, lobbying has a negative connotation due to secret negotiations and unfair benefits. The OECD developed a general framework for lobbying, based on transparency, accountability and integrity. This framework includes disclosure standards for lobbying activities. Public policy may introduce (enhanced) mandatory disclosure rules for lobbying in the field of taxation.

\subsection{Countermeasures Increasing the Opportunity Cost}

Earlier, we argued that the opportunity cost of not investing in sustainable tax behavior is also an important value-driver (See Section 2.2). First, as explained above, delaying the decision to invest in sustainable tax planning exposes the firm to a reputational risk as long as such a decision has not been taken. However, an actual reputational risk is only present if these stakeholders have sufficient information on that tax strategy. So far, however, tax planning strategies have been opaque [27]. Transparency on aggressive tax planning and the subsequent negative sentiment in public opinion largely comes from activist NGOs and journalists that have found information on multinationals' tax strategies based on their investigations, not publicly available information. The disclosure of this information in the media has had some impact on the other stakeholders [69]. For instance, this explains why Starbucks, after the company's aggressive tax planning structures had been mediatized, voluntarily paid around ten million pounds in additional taxes to United Kingdom's Her Majesty's Revenue \& Customs ('HMRC') in order to safeguard its reputation [70]. However, [71] found that the reputational cost resulting from journalists accusing companies of tax shelter involvement is only temporary. As mentioned above, NGOs and journalists are (only) indirect stakeholders which may influence direct stakeholders. The Real Option Theory shows that governments may want to introduce transparency measures which also focus on direct stakeholders. 
As explained above, the OECD BEPS Action Plan and the new EU rules introduce transparency measures which, accordingly, increase the reputational risk, but only vis-à-vis one specific direct stakeholder, i.e., the tax authorities. The Real Option Theory shows that transparency vis-à-vis all relevant stakeholders is important. As mentioned above, this also encompasses clients, shareholders and other finance-providers, and employees. Currently, these direct stakeholders, however, do not have access to detailed information on a company's tax strategy in most countries. Tax reporting has "historically been opaque" [72]. In addition, based on qualitative research, [73] show how, despite corporate social responsibility commitments with respect to accurate and transparent communication, companies make only limited disclosures on taxation, and completely omit issues such as tax planning, tax risks and tax compliance.

Insofar as stakeholders lack access to information on the company's tax strategy, the reputational risk remains limited. The reputational risk can be increased by introducing public policy interventions that provide transparency vis-à-vis all relevant stakeholders, not just the tax authorities. This resonates with the proposal at the EU level to introduce public country-by-country reporting, or suggestions to introduce other mandatory public tax reporting requirements for multinationals, such as the disclosure of aggressive tax planning positions or other corporate income tax data.

Next, while public disclosure may trigger a negative connotation with 'naming and shaming' [65], the Real Option Theory shows that public disclosure should also be looked at from another angle. Companies adopting and disclosing sustainable tax behavior at an early stage benefit from a first-mover advantage, and have the opportunity to set industry standards. Looked at from this angle, the opportunity cost concerns the fact that a company may lose such a first-mover advantage.

For this opportunity to have a positive impact on stakeholder support, however, more is needed. Reference [52] indicates that, for investments to actually result in a first-mover advantage, it is very important that these initiatives are made visible to the stakeholders. In order to increase visibility, previous research has suggested the incorporation of tax compliance into corporate social responsibility reporting and other communication mechanisms developed by NGO's, or to incorporate 'tax strategy' as an assessment criterion in sustainability indices [2].

The credibility of the source for visibility is a key factor in attracting stakeholders' attention [52]. This suggests that the support of not only NGO's but also governments in making sustainable tax behavior initiatives visible has an important impact. A good example of this can be seen in the Code of Practice on Taxation for Banks that was introduced by the HMRC in 2009. The Code provides guidance for governance and tax planning. Furthermore, the HMRC publishes an annual report on the application of the code. This report discloses the name of banks which apply the Code, as well as any bank not applying or breaching the Code. The OECD and the EU may consider developing instruments stimulating the (voluntary) reporting of sustainable tax behavior.

\subsection{Countermeasures Reducing the Option Window}

Finally, real option logic also shows that the option window is a relevant value-driver. The interventions suggested above may be accompanied by interventions that influence the length of the option window by threatening to impose more direct enforcement types of interventions that close the window. Since the OECD, however, has no competences, it is difficult for this organization to influence this value-driver. The European Union, on the contrary, has certain competences that are useful for having an impact on the option window. This value-driver can explain that the current investigations of the European Commission in the framework of EU state aid rules are efficient for combatting aggressive tax planning. In 2016, for instance, the European Commission decided that the beneficial tax treatment of the income of Apple's 'head office' in Ireland constitutes illegal state aid. The same year, Facebook announced that its sales structure would be changed. Going forward, the non-American sales would no longer be organized through its Irish 'head office' of Facebook, but accounting profits would be registered locally. As a result, Facebook is expected to pay taxes on net profits in 30 countries, including Germany, France, Spain, Italy, the Netherlands, Belgium, Norway, 
Poland and Sweden [74]. This illustrates that the enforcement actions also impact other taxpayers. This can be explained by the fact that the latter consider that, as a result of the actions of the EC, the option window to freely choose sustainable tax behavior becomes shorter.

\section{Conclusions}

Based on a traditional net present value approach, one may assume that decision to shift from aggressive tax planning to more sustainable tax behavior is taken as soon as the benefits of sustainable tax behavior (e.g., reputation building) exceed the investment cost (e.g., additional tax payments). However, the Real Option Theory shows that, because of the uncertainty that surrounds the benefits of sustainable tax behavior, more than simply exceeding the benefits is needed for companies to take such a decision. Postponing the investment offers the advantage of being able to gather more information with respect to the uncertain environment.

We have shown that looking at investment in sustainable tax behavior from a real option framework allows for a more accurate and realistic perspective, and a richer set of value-drivers. Countermeasures adopted so by far the OECD or at EU level mainly reduce the investment cost of sustainable tax planning, but do not address other important value-drivers, such as the uncertainty surrounding the benefits of sustainable tax behavior, the opportunity cost of delaying sustainable tax planning and the time frame of delaying.

Finally, we suggested some public policy interventions that address these three value-drives. These interventions aim to clarify the boundary between aggressive tax planning and sustainable tax behavior, increasing transparency to all relevant stakeholders through self-regulation or otherwise, and reducing the time window by threatening more direct enforcement actions. From our analysis, it is shown that diversifying the range of interventions to these additional ones aiming directly at reducing this real option value (of waiting) is needed to make public interventions in stimulating STB effective and stop companies from dragging their feet in switching to it today.

Author Contributions: Conceptualization, D.C., P.-J.E., and A.V.d.V.; methodology, D.C. and P.-J.E.; writing-original draft preparation, A.V.d.V., D.C. and P.-J.E.; writing-review and editing, A.V.d.V., D.C. and P.-J.E.; visualization, P.-J.E. All authors have read and agreed to the published version of the manuscript.

Funding: This research received no external funding.

Acknowledgments: We thank the editor and five reviewers for their useful comments.

Conflicts of Interest: The authors declare no conflict of interest.

\section{Appendix A. The Black-Scholes Model}

The Black-Scholes value of a European call option (in real option terms) is equal to [46]

$$
E C=V e^{-\delta(T-t)} N\left(d_{1}\right)-I e^{-r(T-t)} N\left(d_{2}\right)
$$

with

$$
d_{1}=\frac{\ln (V / I)+\left(r-\delta+0.50 \sigma^{2}\right)(T-t)}{\sigma \sqrt{T-t}}
$$

and

$$
d_{2}=d_{1}-\sigma \sqrt{T-t}
$$

where:

- $E C=$ the value of the real option;

- $V=$ the present value of the expected benefits of the real option;

- $\delta=$ the opportunity cost;

- $T-t=$ time to maturity, or window of opportunity;

- $r=$ the risk-free interest rate; 
- $\quad I=$ the investment cost of the real option;

- $\sigma=$ the standard deviation of the underlying asset's return;

- $\quad N(d)=$ the cumulative normal probability density function operator.

\section{References}

1. Desai, M.A.; Dharmapala, D. Corporate Tax Avoidance and High-Powered Incentives. J. Financ. Econ. 2006, 79, 145-179. [CrossRef]

2. Bird, R.; Davis-Nozemack, K. Tax Avoidance as a Sustainability Program. J. Bus. Ethics 2016. [CrossRef]

3. Gribnau, H.; Jallai, A.G. Sustainable Tax Governance and Transparency. Tilburg Law School Research Paper. 2018. Available online: https://ssrn.com/abstract=3273553 (accessed on 21 May 2020).

4. Schratzenstaller, M. Sustainable tax policy: Concepts and indicators beyond the tax ratio. Rev. L'ofce 2015, 141, 57-77. [CrossRef]

5. OECD (2018-2019). OECD Work on Taxation, OECD Publishing, Paris. Available online: https://www.oecd. org/tax/centre-for-tax-policy-and-administration-brochure.pdf (accessed on 10 March 2020).

6. Avi-Yonah, R.S. Corporate social responsibility and strategic tax behavior in Tax and corporate governance. In Tax and Corporate Governance; Schön, W., Ed.; Springer: New York, NY, USA, 2008; pp. 183-198.

7. European Parliament. Bringing transparency, coordination and convergence to corporate tax policies in the European Union. I. In Assessment of the Magnitude of Aggressive Corporate Tax Planning; European Parliament: Brussels, Belgium, 2015.

8. European Commission. Aggressive Tax Planning Indicators; Final Report, Working Paper no. 71-2017; European Commission: Brussels, Belgium, 2017.

9. Internal Revenue Service Research. Applied Analytics \& Statistics Federal Tax Compliance Research: Tax Gap Estimates for Tax Years 2011-2013 Publication 1415 (Rev. 9-2019); Internal Revenue Service Research: Washington, DC, USA, 2019.

10. Mills, L. Barriers to improving tax capacity. In K4D Helpdesk Report; Institute of Development Studies: Brighton, UK, 2017.

11. OECD. Two-Part Report to G20 Development Working Group on the Impact of BEPS in Low Income Countries; OECD Publishing: Paris, France, 2014; Available online: https:/www.oecd.org/ctp/tax-global/part-2-ofreport-to-g20-dwg-on-the-impact-of-beps-in-low-income-countries.pdf (accessed on 10 March 2020).

12. Wier, L. Tax-motivated transfer mispricing in South Africa: Direct evidence using transaction data. J. Public Econ. 2020, 184, 1-16. [CrossRef]

13. Vet, C.; Cassimon, D.; Van de Vijver, A. Why Sub-Saharan African Countries Only Get to Tax the Crumbs of Corporate Synergy Profits. A Content Analysis of the Revised Transactional Profit Split Method Unravelling Unequal Power in Global Tax Governance, Institute of Development Policy, University of Antwerp, Working Paper, No. 2019.04. 2019. Available online: https://www.uantwerpen.be/images/uantwerpen/container2673/ files/Publications/WP/2019/wp-201904.pdf (accessed on 20 December 2019).

14. McGauran, K. Should the Netherlands Sign Tax Treaties with Developing Countries? Centre for Research on Multinational Corporations: Amsterdam, The Netherlands, 2013.

15. Tørsløv, T.; Wier, L.; Zucman, G. The Missing Profit of Nations, NBER Working Paper No. w24701. 2018. Available online: https://ssrn.com/abstract=3194743 (accessed on 3 April 2020).

16. Jallai, A.G. Restoring Stakeholders' Trust in Multinationals' Tax Planning Practices with Corporate Social Responsibility (CSR). In Building Trust in Taxation; Peeters, B., Gribnau, H., Badisco, J., Eds.; Intersentia: Mortsel, Belgium, 2017; pp. 173-201.

17. Braithwaite, V.; Wenzel, M. Integrating explanations of tax evasion and avoidance. In The Cambridge Handbook of Psychology and Economic Behaviour; Lewis, A., Ed.; Cambridge University Press: Cambridge, UK, 2008; pp. 304-331.

18. Thuronyi, V.; Brooks, K.; Kolozs, B. Comparative Tax Law; Wolters Kluwer: Alphen aan den Rijn, The Netherlands, 2016.

19. OECD. OECD Guidelines for Multinational Enterprises; OECD Publishing: Paris, France, 2011.

20. OECD. Action Plan on Base Erosion and Profit Shifting; OECD Publishing: Paris, France, 2013.

21. Hardeck, I.; Hertl, R. Consumer Reactions to Corporate Tax Strategies: Effects on Corporate Reputation and Purchasing Behavior. J. Bus. Ethics 2014, 123, 309-326. [CrossRef] 
22. Gribnau, H. The Integrity of the Tax System after BEPS: A Shared Responsibility. ELR 2017, 10, 12-28. [CrossRef]

23. Friese, A.; Link, S.; Mayer, S. Taxation and corporate governance-State of the art. In Tax and Corporate Governance; Schön, W., Ed.; Springer: New York, NY, USA, 2008; pp. 357-425.

24. Council of the EU. Council Directive (EU) 2016/1164 of 12 July 2016 Laying down Rules against Tax Avoidance Practices That Directly Affect the Functioning of the Internal Market, OJ L 193, 19 July 2016. pp. 1-14. Available online: http://data.europa.eu/eli/dir/2016/1164/oj (accessed on 20 March 2020).

25. Council of the EU. Council Directive (EU) 2015/2376 of 8 December 2015 Amending Directive 2011/16/EU as Regards Mandatory Automatic Exchange of Information in the Field of Taxation, OJ L 332, 18 December 2015. pp. 1-10. Available online: http://data.europa.eu/eli/dir/2015/2376/oj (accessed on 20 March 2020).

26. Council of the EU. Council Directive (EU) 2016/881 of 25 May 2016 Amending Directive 2011/16/EU as Regards Mandatory Automatic Exchange of Information in the Field of Taxation, OJ L 146, 3 June 2016. pp. 8-21. Available online: http://data.europa.eu/eli/dir/2016/881/oj (accessed on 20 March 2020).

27. Council of the EU. Council Directive (EU) 2018/822 of 25 May 2018 Amending Directive 2011/16/EU as Regards Mandatory Automatic Exchange of Information in the Field of Taxation in Relation to Reportable Cross-Border Arrangements. Available online: http://data.europa.eu/eli/dir/2018/822/oj (accessed on 20 March 2020).

28. Kim, J.; Im, C. Study on corporate social responsibility (CSR): Focus on tax avoidance and financial ratio analysis. Sustainability 2017, 9, 1710. [CrossRef]

29. Li, W.; Lu, Y.; Li, W. Does CSR Action Provide Insurance-Like Protection to Tax-Avoiding Firms? Evidence from China. Sustainability 2019, 11, 5297. [CrossRef]

30. Gulzar, M.A.; Cherian, J.; Sial, M.S.; Badulescu, A.; Thu, P.A.; Badulescu, D.; Khuong, N.V. Does Corporate Social Responsibility Influence Corporate Tax Avoidance of Chinese Listed Companies? Sustainability 2018, 10, 4549. [CrossRef]

31. European Commission. Press Release, State Aid: Commission Opens in-Depth Investigation into Tax Treatment of Huhtamäki in Luxembourg; European Commission: Brussels, Belgium, 2019.

32. Allingham, M.G.; Sandmo, A. Income Tax Evasion: A Theoretical Analysis. J. Public Econ. 1972, 1, $323-338$. [CrossRef]

33. Engelen, P.J.; Lander, M.W.; van Essen, M. What determines crime rates? An empirical test of integrated economic and sociological theories of criminal behavior. Soc. Sci. J. 2016, 53, 247-262. [CrossRef]

34. Alm, J. Designing alternative strategies to reduce tax evasion. In Tax Evasion and the Shadow Economy; Pickhardt, M., Prinz, A., Eds.; Edward Elgar Publishing: Cheltenham, UK, 2012; pp. 13-32.

35. Andreoni, J.; Erard, B.; Feinstein, J. Tax Compliance. J. Econ. Lit. 1998, 36, 818-860.

36. Kleven, H.J.; Knudsen, M.B.; Kreiner, C.T.; Pedersen, S.; Saez, E. Unwilling or unable to cheat? Evidence from a tax audit experiment in Denmark. Econometrica 2011, 79, 651-692.

37. Engelen, P.J.; Cassimon, D. Real options. In Encyclopedia of Law and Economics; Backhaus, J., Ed.; Springer: New York, NY, USA, 2015; pp. 1-10.

38. McDonald, R.; Siegel, D. The Value of Waiting to Invest. Q. J. Econ. 1986, 101, 707-728. [CrossRef]

39. Trigeorgis, L. Real Options; MIT Press: Cambridge, UK, 1996.

40. Cassimon, D.; De Backer, M.; Engelen, P.J.; Van Wouwe, M.; Yordanov, V. Incorporating technical risk in compound real option models to value a pharmaceutical R\&D licensing opportunity. Res. Policy 2011, 40, 1200-1216.

41. Sanders, M.; Fuss, S.; Engelen, P.J. Mobilizing Private Funds for Carbon Capture and Storage: An exploratory field study in the Netherlands. Int. J. Greenh. Gas Control 2013, 19, 595-605. [CrossRef]

42. Engelen, P.J. Criminal behavior: A real option approach. With an application to restricting illegal insider trading. Eur. J. Law Econ. 2004, 17, 329-352. [CrossRef]

43. Cassimon, D.; Engelen, P.J.; Reyntjens, F. Rwanda's involvement in Eastern DRC: A criminal real options approach. CrimeLawSoc. Chang. 2013, 59, 39-62. [CrossRef]

44. Cassimon, D.; Engelen, P.J.; Van Liedekerke, L. When do firms invest in corporate social responsibility? A real option framework. J. Bus. Ethics 2016, 137, 15-29. [CrossRef]

45. Cassimon, D.; Engelen, P.J. Option Prices Models. In Encyclopedia of Law and Economics; Marciano, A., Ramello, G.B., Eds.; Springer: New York, NY, USA, 2016; pp. 1-6.

46. Black, F.; Scholes, M. The Pricing of Options and Corporate Liabilities. J. Polit. Econ. 1973, 81, 637-659. [CrossRef] 
47. Husted, B.W. Risk management, real options, corporate social responsibility. J. Bus. Ethics 2005, 60, 175-183. [CrossRef]

48. Lanis, R.; Richardson, G. Corporate social responsibility and tax aggressiveness: An Empirical Analysis. J. Account. Public Policy 2012, 31, 86-108. [CrossRef]

49. Fisher, J.M. Fairer Shores: Tax Havens, Tax Avoidance, and Corporate Social Responsibility. Boston Univ. Law Rev. 2014, 94, 337-366.

50. Dowling, G.R. The Curious Case of Corporate Tax Avoidance. J. Bus. Ethics 2014, 124, 173-184. [CrossRef]

51. Hanlon, M.; Slemrod, J. What does tax aggressiveness signal? Evidence from stock price reactions to news about tax shelter involvement. J. Public Econ. 2009, 93, 126-141. [CrossRef]

52. Sirsly, C.A.T.; Lamertz, K. When does a corporate social responsibility initiative provide a first-mover advantage? Bus. Soc. 2008, 47, 343-369. [CrossRef]

53. Knuutinen, R. Corporate Social Responsibility, Taxation and Aggressive Tax Planning. Nord. Tax J. 2014, 1, 36-75. [CrossRef]

54. Pampel, F.; Andrighetto, G.; Steinmo, S. How Institutions and Attitudes Shape Tax Compliance: A Cross-National Experiment and Survey. Soc. Forces 2019, 97, 1337-1364. [CrossRef]

55. Torgler, B. Cross-culture comparison of tax morale and tax compliance: Evidence from Costa Rica and Switzerland. Int. J. Comp. Sociol. 2004, 45, 17-43. [CrossRef]

56. Panayi, C. International Tax Law Following the OECD/G20 Base Erosion and Profit Shifting Project. Bull. Ibfd 2016, 70, 628-660.

57. De Graaf, A.; Visser, J.K. BEPS: Will the Current Commitments and Peer Review Model Prove Effective? Ec Tax Rev. 2018, 1, 36-47.

58. OECD. Countering Harmful Tax Practices More Effectively, Taking into Account Transparency and Substance, Action 5-2015 Final Report; OECD Publishing: Paris, France, 2015.

59. OECD. Transfer Pricing Documentation and Country-by-Country Reporting, Action 13-2015 Final Report; OECD Publishing: Paris, France, 2015.

60. European Commission. Proposal for a Directive of the European Parliament and of the Council Amending Directive 2013/34/EU As Regards Disclosure of Income Tax Information by Certain Undertakings and Branches, COM/2016/0198 Final-2016/0107 (COD); European Commission: Brussels, Belgium; Available online: https://eur-lex.europa.eu/legal-content/EN/TXT/?qid=1593615085387\&uri=CELEX:52016PC0198 (accessed on 20 March 2020).

61. EPSU, EFFAT, SEIU. Unhappier Meal Report. Tax Avoidance Still on the Menu at McDonald's, Brussels. 2018. Available online: https:/www.taxjustice.net/2018/05/14/unhappy-meal-tax-avoidance-still-on-themenu-at-mcdonalds/ (accessed on 16 May 2018).

62. Avi-Jonah, R.S.; Xun, H. Evaluating BEPS. Erasmus Law Rev. 2017, 10, 3-11. [CrossRef]

63. Eurodad. Survival of the Richest, Europe's Role in Supporting an unjust Global Tax System 2016. 2017. Available online: https://eurodad.org/Entries/view/1546667/2016/12/06/Survival-of-the-richest-Europe-srole-in-supporting-an-unjust-global-tax-system-2016 (accessed on 3 July 2020).

64. Baudot, L.; Johnson, J.A.; Roberts, A.; Roberts, R.W. Is Corporate Tax Aggressiveness a Reputation Threat? Corporate Accountability, Corporate Social Responsibility, and Corporate Tax Behavior. J. Bus. Ethics 2020, 163, 197-215. [CrossRef]

65. Blank, J. What's Wrong with Shaming Corporate Tax Abuse. Tax L. Rev. 2009, 62, 539-590.

66. McGlone, T.; Winters Spain, J.; McGlone, V. Corporate Social Responsibility and the Millennials. J. Educ. Bus. 2011, 86, 195-200. [CrossRef]

67. Berzau, L. The Business Social Compliance Initiative A system for the continuous improvement of social compliance in global supply chains. Z. Fuer Wirtsch. 2011, 12, 139-141. [CrossRef]

68. Jallai, A.G.; Gribnau, H. Aggressive Tax Planning and Corporate Social Irresponsibility: Managerial Discretion in the Light of Corporate Governance; Tilburg Law School Legal Studies Research Paper Series, No. 05/2018; Tilburg Law School: Tilburg, The Netherlands, 2018.

69. Kanagaretnam, K.; Lee, J.; Yeow Lim, C.; Lobo, G.J. Cross-country evidence on the role of independent media in constraining corporate tax aggressiveness. J. Bus. Ethics 2016. [CrossRef]

70. Van den Hurk, H. Tax Planning, Ethics and Our New World. Bull. Int. Tax. 2018, 72, 122-128.

71. Gallemore, J.; Maydew, E.L.; Thornock, J.R. The Reputational Costs of Tax Avoidance. Contemp. Account. Res. 2014, 31, 1103-1133. [CrossRef] 
72. Gradison, B.; Reilly, M.P.; Wheeler, R.D.; Wilkins, W.J.; Wylie, R.S. A Path Forward-Best Practices and Possible Policy Changes. Taxes 2006, 84, 113-139.

73. Ylönen, M.; Laine, M. For logistical reasons only. A case study of tax planning and corporate social responsibility reporting. Crit. Perspect. Account. 2015, 33, 5-23. [CrossRef]

74. BBC News online. Facebook to Overhaul Irish Tax Scheme, 12 December 2017. Available online: http: //www.bbc.com/news/business-42324485 (accessed on 21 March 2020).

(C) 2020 by the authors. Licensee MDPI, Basel, Switzerland. This article is an open access article distributed under the terms and conditions of the Creative Commons Attribution (CC BY) license (http://creativecommons.org/licenses/by/4.0/). 